NEWS

\title{
Biodefence lab criticized
}

\author{
US lawmakers investigate site choice of planned facility.
}

The US government's decision to locate a new national biosecurity lab in Manhattan, Kansas, has been called into question by a congressional watchdog. The Government Accountability Office (GAO) concluded that the Department of Homeland Security (DHS) relied on a flawed risk assessment when deciding the location of the US\$650-million National Bio and Agro-Defense Facility.

Last December the DHS chose Kansas State University as the site of a high-containment lab to replace the Plum Island Animal Disease Center in New York state.

But the GAO found that the department used "unrepresentative accident scenarios", "outdated modelling", and "inadequate" information in assessing the chance that highly contagious pathogens might be accidentally released from the facility, according to a draft of the report obtained by The Washington Post. The full report was scheduled to be released on 30 July, to coincide with a hearing convened by the House Committee on Energy and Commerce's over-

sight and investigations subcommittee.

The GAO says that the DHS's environmental impact statement, prepared for all six finalist sites, did not adequately evaluate worst-case scenarios.

Matthew Chandler, a DHS spokesman, defended the agency's site selection process as open, fair and safe. "We stand by our process," he says. A GAO spokeswoman declined to

"We have the technology to work with these agents safely." comment on the draft report.

Jerry Jaax, Kansas State University's associate vice-president for research compliance, says that concerns about placing the high-containment lab on the US mainland are "outmoded". He says that no problems have been found at other mainland disease facilities operating at the highest biosecurity level, such as those at the Centers for Disease Control and Prevention in Atlanta, Georgia, and the DHS's biodefence lab in Fort Detrick, Maryland. In addition, worries over a risk of tornados at the site are "disingenuous and stupid", he says. "The safest place in the case of a

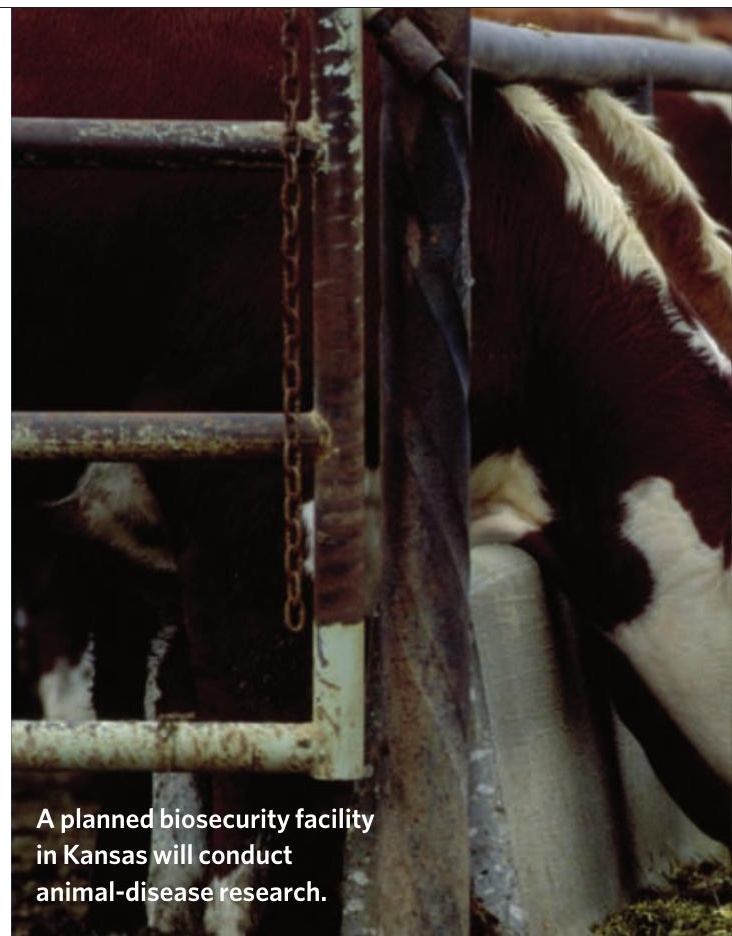

tornado would be one of these facilities."

Michael Guiffré, a partner at law firm Patton Boggs in Washington DC who represents a consortium seeking to site the biosecurity lab in San Antonio, Texas, applauded the report and called for a full comparison of

\section{Physicians fight back against disclosure rules}

BOSTON, MASSACHUSETTS

Even as US legislators work to limit ties between academic physicians and industry, a small group of doctors is calling for greater industry collaboration. On 23 July, they gathered at Brigham and Women's Hospital in Boston to launch a new organization opposed to strict conflict-of-interest rules.

The Association of Clinical Researchers and Educators (ACRE) is the brainchild of Thomas Stossel, a haematologist at Harvard Medical School. Stossel has been a vocal critic of conflict-of-interest rules since the late 1980s, when he was on the board of the Cambridgebased biotech firm Biogen and Harvard adopted its first conflict-ofinterest policy.

“Tom, for many years, was pretty much the lone voice," says Laurence Hirsch, an endocrinologist with the medical-technology firm BD in Franklin Lakes, New Jersey.

Now, however, Stossel has company. He and the five other physicians who lead ACRE argue that they are part of a "silent majority" who think the move to curtail physician-industry relations has gone too far. In Massachusetts, a law came into effect on 1 July that requires drug and medical-device manufacturers to inform the state health department about payments of $\$ 50$ or more

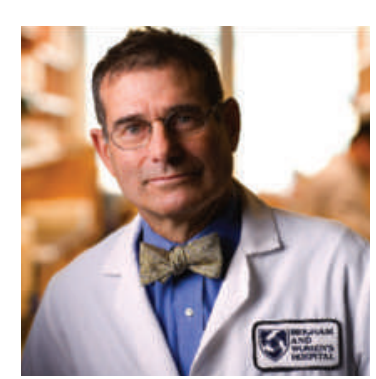

Thomas Stossel: vocal critic of conflict-of-interest rules. that would set up a national reporting requirement.

ACRE does not yet oppose specific laws, it says, but rather the climate of distrust it claims tough conflict-of-interest rules create. The notion that a physician is automatically tainted by financial interest in a company is "obnoxious", says Michael Weber, a cardiologist at the State University of New York Downstate Medical Center in Brooklyn, and a member of ACRE's made to physicians for marketing activities; gifts are banned. Vermont has adopted a tougher law, and Congress is considering legislation steering committee. "Just because something is good for industry doesn't mean it has to be bad for everyone else."
Still, last year, a congressional investigation revealed that three Harvard psychiatrists had reported to their university only a fraction of the million or more dollars each received from drug companies. And psychiatrist Charles Nemeroff of Emory University in Atlanta, Georgia, stepped down after the same probe uncovered that he failed to report at least $\$ 1.2$ million he earned from drug companies. "I do not believe that a physician that takes more than a million dollars in money from industry can possibly be objective," says cardiologist Steven Nissen of the Cleveland Clinic in Ohio, a strong supporter of curbing industryphysician ties.

Not all instances are so clear-cut, argued some at the ACRE meeting. After Hurricane lke destroyed the cafeteria and much of the first 
